HUMANIKA Vol. 19 No. 1 (2014) ISSN 1412-9418

Penataan Drainase Perkotaan Berbasis Budaya

Titiek Suliyati

\title{
PENATAAN DRAINASE PERKOTAAN BERBASIS BUDAYA DALAM UPAYA PENANGANAN BANJIR DI KOTA SEMARANG
}

\author{
Titiek Suliyati \\ Fakultas Ilmu Budaya Universitas Diponegoro \\ J1. Prof. H. Soedarto, SH Tembalang Semarang 50275 \\ Email: titiek.suliyati@yahoo.com
}

\begin{abstract}
Flood happened in most of Indonesian areas is basically because of the condition of nature and human conduct. As any other cities in Indonesia, Semarang is a city that never free from flood and it is getting worse and worse each year. Ten to sixteen subdistricts are flooded increasingly each year, among others Northern, Eastern and Western Semarang. Histotically, Semarang is never free from flood. Through forced labour, in 1850 and 1896 Dutch colonizer built two big cannals, called East Banjirkanal (Banjirkanal Timur) and West Banjirkanal (Banjirkanal Barat) anticipating flood in Northern Semarang that becomes business center in Semarang harbour. East Banjirkanal was built to anticipate flood in East Semarang and the development area of Semarang harbour. Originally those cannals built to flow water from the upper part of Semarang (area of Semarang district on the foot of Ungaran hill). Flood problem should be handled not only by structural method, such as building infrastructure, but also by non-structure method namely social and socio cultural aspects. To overcome flood in Semarang, wholy and integratedly starting from planning phase, execution, reconstruction, evaluation and revitalization should be carried out. In planning activities, synoptic comprehensive and transactive or social learning are applied. Synoptic comprehensive planning is applied to study technical problems and policies related to execute the technical execution. Administered synoptic comprehensive is comprehensively, inter-sectors and administration. Transactive or social learning is stressed on social participation related to awereness, objective and education related to culture that nurture the environment maintenance.
\end{abstract}

Keywords: Penataan, drainase, banjir, perkotaan, budaya

\section{PENDAHULUAN}

Banjir yang terjadi di beberapa wilayah Indonesia pada umumnya merupakan gabungan dari kondisi alam dan perbuatan manusia. Seperti halnya kota-kota lain di Indonesia yang mengalami perubahan dan kerusakan alam yang parah, kota Semarang merupakan salah satu kota yang sepanjang tahun mengalami banjir yang kondisinya cenderung semakin parah. Selama sepuluh tahun terakhir 10 kecamatan dari 16 kecamatan yang 
HUMANIKA Vol. 19 No. 1 (2014) ISSN 1412-9418

Penataan Drainase Perkotaan Berbasis Budaya

Titiek Suliyati

ada di kota Semarang mengalami banjir yang potensinya selalu meningkat. Kecamatan yang terendam banjir antara lain Semarang Utara, Semarang Timur, Semarang Barat, Tugu, Ngaliyan, Semarang Tengah, Genuk, Gayamsari, Pedurungan, dan Semarang Selatan. Banjir di wilayahwilayah tersebut tahun terakhir mencapai ketinggian air antara 0,5 ï 1,3 meter.

Dalam catatan sejarah Semarang tidak pernah lepas dari ancaman banjir.Terbukti bahwa sejak jaman pemerintahan kolonial Belanda telah ada upaya untuk menanggulangi masalah banjir di kota Semarang, yaitu membangun dua kanal besar pada sisi barat dan timur kota Semarang. Pembangunan dua kanal ini dilakukan melalui kerja wajib (heren diensten). Banjirkanal Barat (West Bandjirkanaal) dibangun pada Tahun 1850 untuk menganptisipasi banjir di wilayah Semarang Utara, yang menjadi pusat kegiatan dagang di pelabuhan Semarang. Banjirkanal Timur (Oost Bandjirkanaal) dibangun pada tahun 1896-1903 dengan tujuan menghindarkan wilayah Semarang Timur dan wilayah pengembangan pelabuhan Semarang dari ancaman banjir. Tujuan pemerintah kolonial Belanda membangun Banjirkanal Barat dan Banjirkanal Timur pada awalnya adalah untuk mengalirkan air dari wilayah bagian atas kota Semarang (wilayah kabupaten Semarang yang terletak di kaki bukit Ungaran) ke laut.

Perkembangan kota yang pesat menjadikan Semarang sebagai kota yang padat penduduk. Pertambahan penduduk sebagai akibat dari kelahiran dan urbanisasi mengakibatkan perluasan area pemukiman. Perluasan area pemukiman kota ini tentu akan mengurangi area hijau sebagai area resapan air, yang berdampak pada aliran dan luapan air yang semakin deras. Penanggulangan luapan air yang tidak terkendali dalam bentuk banjir memang telah dilakukan oleh pemerintah kota dengan membangun drainase-drainase baru, yang pembangunannya hanya parsial saja. Pembangunan drainase-drainase baru cenderung tanpa perencanaan matang dan mengabaikan fungsi dasar dari pembangunan dua kanal oleh Pemerintah Kolonial Belanda tersebut. Fungsi Banjirkanal Timur dan Banjirkanal Barat sekarang tidak hanya menampung luapan dari wilayah atas Semarang, tetapi juga menampung luapan air dari drainase-drainase di dalam kota. Dengan demikian ketika hujan dua kanal ini tidak dapat menampung luapan air tersebut sehingga air tumpah-ruah ke perkampungan dan jalan yang ada di sekitar dua kanal tersebut.

Penanganan banjir di Semarang harus dilakukan secara terpadu antara semua instansi pemerintah yang terkait dengan penataan sarana dan prasarana perkotaan, masyarakat sebagai unsur yang terlibat maupun terkena dampak dari baik-buruknya penataan sarana dan prasarana perkotaan serta organisasi-organisasi sosial kemasyarakatan yang menjadi pendukung pemberdayaan maupun kesejahteraan masyarakat.

\section{PENYEBAB BANJIR DI SEMARANG}

Banjir di kota Semarang menurut Pramono (2002) disebabkan oleh kondisi fisik dan non fisik. Faktor pertama adalah kondisi geografis kota Semarang yang memiliki daerah- 
daerah potensi banjir, karena ada wilayah yang terletak di daerah yang tinggi dan wilayah yang terletak di daerah dataran rendah, menyebabkan banjir kiriman yang berasal dari wilayah selatan Kota Semarang dan kabupaten Semarang. Selain itu banyak sungai yang berhulu di daerah Kabupaten Semarang melewati Kota Semarang. Faktor kedua adalah perubahan pemanfaatan lahan dari hutan karet menjadi perumahan di wilayah kecamatan Mijen memperbesar kerusakan di daerah tersebut. Akibatnya jumlah air hujan yang mengalir ke wilayah Ngaliyan menjadi bertambah dan membuat daerah tersebut terkena musibah banjir, padahal sebelumnya di daerah tersebut belum pernah terkena banjir. Selain penggundulan hutan, perubahan fungsi lahan yang terjadi di wilayah Kabupaten Semarang dari area pertanian menjadi areal perumahan baru. Faktor ketiga, adanya pengeprasan bukit di beberapa tempat mengakibatkan perubahan pola aliran air, erosi, dan mempertinggi kecepatan air, sehingga membebani pengairan. Faktor keempat, pembangunan rumah liar di atas bantaran sungai, pembuatan tambak yang mempersempit sungai dan penutupan saluran di daerah hilir. Faktor kelima adalah permasalahan non-teknis yaitu perilaku masyarakat kota Semarang yang buruk. Perilaku masyarakat yang tidak peduli terhadap pemeliharaan lingkungan seperti membuang sampah di saluran air dan di sembarang tempat serta menutup saluran drainase untuk bangunan/warung menjadi hal yang biasa.

$\begin{array}{lccr} & \text { Menurut } & \text { Yusuf (2005), } & \text { Banjir } \\ \text { di } \quad \text { kota } & \text { Semarang } & \text { dapat } \\ \text { dikelompokkan } & \text { sebagai } & \text { banjir }\end{array}$

kiriman, banjir lokal, dan banjir rob. Banjir kiriman yang terjadi secara periodik setiap tahun melanda daerah sekitar pertemuan Kali Kreo, Kali Kripik, dan Kali Garang sampai di Kampung Bendungan. Banjir kiriman ini terjadi karena :

a. Peningkatan debit air sungai yang mengalir dari DAS Garang, DAS Kreo, dan DAS Kripik yang disebabkan oleh intensitas hujan yang besar, atau intensitas hujan yang sama namun jatuh pada wilayah yang telah berubah atau telah mengalami konversi penggunaan lahan.

b. Berkurangnya daya tampung saluran atau sungai, sehingga air meluap menggenangi daerah di sekitarnya.

c. Banjir kiriman semakin besar volumenya oleh kiriman air dari daerah atas sebagai akibat bertambah luasnya daerah terbangun yang mengurangi luasan daerah resapan

Banjir lokal yang lebih bersifat setempat, terjadi disebabkan oleh intensitas hujan yang tinggi, sarana drainase yang tidak memadai dan penggunaan saluran untuk berbagai tujuan (multipurpose) baik untuk penyaluran air hujan, limbah, dan sampah rumah tangga. Kondisi banjir lokal semakin buruk dengan pembangunan fasilitas umum yang tidak terkoordinasi seperti penanaman pipa air minum oleh PDAM, kabel telpon oleh TELKOM dan kabel listrik oleh PLN.

Banjir rob yang melanda daerahdaerah di pinggiran laut atau pantai disebabkan oleh permukaan tanah yang lebih rendah daripada permukaan air laut dan bertambah tingginya pasang 
HUMANIKA Vol. 19 No. 1 (2014) ISSN 1412-9418

Penataan Drainase Perkotaan Berbasis Budaya

Titiek Suliyati

air laut. Selain itu sedimentasi di muara Kali Semarang, Banjir Kanal Barat, Kali Silandak, Kali Banger, Silandak Flood Way, Baru Flood Way, dan kali Asin menyebabkan terjadinya pendangkalan muara yang berakibat mengurangi kapasitas penyaluran air.Kondisi ini mengakibatkan banjir di wilayah sekitarnya.

\section{PENANGANAN SEMARANG}

BANJIR

Penanganan masalah banjir selain melalui metode struktur yaitu hal-hal yang bersifat teknik, seperti pembangunan infrastruktur, juga melalui metode non-struktur yang berkaitan dengan aspek kemasyarakatan dan sosial-budaya. Upaya penanganan banjir kota Semarang harus dilakukan secara menyeluruh dan terpadu mulai dari tahap perencanaan, pelaksanaan, evaluasi, rekonstruksi dan revitalisai. Dalam pembuatan perencanaan digunakan pendekatan sinoptik komprehensif dan transaktif atau sosial learning. Perencanaan sinoptik komprehensif untuk mengkaji masalahmasalah yang bersifat teknis dan kebijakan-kebijakan yang pemerintah kota terkait dengan pelaksanaan teknis tersebut. Pendekatan sinoptik komprehensif dalam pelaksanaanya harus dilaksanakan secara terpadu dan lintas sektoral serta lintas administratif. Perencanaan transaktif atau sosial learning ditekankan pada partisipasi masyarakat terkait dengan penyadaran dan arahan serta pendidikan yang terkait dengan budaya yang memumbuhkan kepedulian terhadap pemeliharaan lingkungan. Pendekatan transaktiflsosial learning ini lebih sulit dan membutuhkan waktu lebih lama karena merubah perilaku masyarakat (Hadi, Sudharto, 2005). Namun demikian pendekatan ini dapat diharapkan keberhasilannya dalam penataan lingkungan yang berkelanjutan.

Pendekatan transaktiflsosial learning sebenarnya dapat dilakukan melalui sosialisasi tentang budaya yang terkait dengan kearifan lokal dalam menangani masalah lingkungan seperti penanganan masalah banjir yang dikarenakan sistem drainase yang buruk. Masyarakat perlu disadarkan bahwa budaya menjaga kebersihan lingkungan terutama saluran drainase yang ada disekitarnya perlu dilakukan secara mandiri dan berkesinambungan. Melalui kegiatan secara gotong royong masyarakat dapat memelihara dan merawat saluran drainase di sekitarnya, yang pada akhirnya akan menanggulangi masalah banjir. Yang menjadi masalah adalah bahwa kegiatan gotong royong di lingkungan masyarakat perkotaan sudah luntur, karena kehidupan masyarakat kota yang materialistis dan egois. Tradisi gotong royong dan tradisi òbersih kampungò perlu ditumbuhkan kembali dalam upaya meningkatkan kesejahteraan dan kenyamanan masyarakat karena terhindar dari banjir.

Banjir yang melanda kota Semarang dan sekitarnya setiap tahun seakan sudah menjadi rutinitas tahunan. Penyebab Banjir menurut Kodoatie dan Sjarief (2005), antara lain perubahan tata guna lahan (land-use) di daerah aliran sungai, pembuangan sampah, erosi dan sedimentasi, kawasan kumuh di sepanjang sungai/drainase, perencana-an sistem pengendalian banjir tidak tepat, curah hujan, pengaruh fisio- grafi/geofisik 
sungai, kapasitas sungai, kapasitas drainase yang tidak memadai, pengaruh air pasang, penurunan tanah dan rob, drainase lahan, bendung dan bangunan air, serta kerusakan bangunan pengendali banjir. Perubahan tata guna lahan merupakan penyebab utama banjir dibandingkan dengan penyebab yang lainnya.

Solusi banjir di Kota Semarang menurut Yusuf (2005), meliputi langkah-langkah untuk menangani banjir lokal, banjir genangan, dan banjir rob.Untuk menangani banjir lokal perlu diambil langkah-langkah yaitu di Semarang Barat perlu dibangun saluran sabuk, di daerah hilir perlu normalisasi Banjir kanal Barat dan banjir kanal Silandak untuk mengembalikan kepada kapasitas rancangan, di daerah hulu (lahan burit) perlu diatur dengan PERDA tentang kawasan terbangun, kawasan konservasi, dan pembuatan sumur resapan sehingga fungsi daerah atas sebagai daerah resapan terjamin.

Untuk menangani banjir genangan perlu diambil langkahlangkah yaitu saluran drainase yang ada sebaiknya digunakan untuk mengalirkan air hujan saja (single purpose) dan perlu dibangun saluran tersendiri untuk limbah dan keperluan lainnya, normalisasi dan pemeliharaan saluran-saluran drainase yang ada, perbaikan inlet yang sesuai dengan kapasitas debit yang harus dialirkan, penyusunan PERDA tentang bangunan bawah tanah untuk infrastruktur PLN, PDAM, TELKOM, atau instansi lainnya dan pengaturan luas lahan terbangun, penyuluhan terhadap masyarakat.

Untuk menangani banjir rob perlu diambil langkah-langkah yaitu pemba-ngunan drainase non-gravitasi di Kali Asin, Kali Baru, dan Kali Banger, pembuatan PERDA pengembangan wilayah pantai (termasuk reklamasi) dan izin bangunan yang dikaitkan dengan IMB, serta penertiban dan memperketat perizinan pengeboran air bawah tanah. Menurut Kodoatie dan Sjarief (2005) beberapa metode pengendalian banjir antara lain:

a. Metode Non-Struktur

Termasuk metode ini antara lain: pengelolaan daerah aliran sungai (DAS), pengaturan tata guna lahan, law enforcement, pengendalian erosi di DAS, pengaturan dan pengem-bangan daerah banjir.

b. Metode Struktur meliputi:

1) Bangunan Pengendali Banjir Yang termasuk metode ini antara lain: bendungan (dam), kolam retensi, pembuatan check dam (penangkap sedimen), bangunan pengurang kemiringan sungai, groundsill, retarding basin, pembuatan polder.

2) Perbaikan dan Pengaturan Sistem Sungai. Yang termasuk metode ini antara lain: sistem jaringan sungai, pelebaran atau pengerukan sungai (normalisasi), perlindungan tanggul, tanggul banjir, sudetan (by pass), floodway.

Dari uraian di atas hal yang terpenting yang menjadi penyebab banjir secara umum adalah tidak berfungsinya sistim drainase secara maksimal. Drainase (drainage, Inggris) mempunyai arti mengalirkan, menguras, membuang, atau mengalirkan air. Secara umum drainase dapat didefinisikan sebagai suatu tindakan teknis untuk mengurangi kelebihan air, baik yang berasal dari air hujan, rembesan, 
HUMANIKA Vol. 19 No. 1 (2014) ISSN 1412-9418

Penataan Drainase Perkotaan Berbasis Budaya

Titiek Suliyati

maupun kelebihan air irigasi dari suatu kawasan/lahan, sehingga fungsi kawasan/lahan tidak terganggu. Drainase dapat juga diartikan sebagai usaha untuk mengontrol kualitas air tanah dalam kaitannya dengan salinitas. Jadi, drainase menyangkut tidak hanya air permukaan tapi juga air tanah (Suripin, 2004).

Pada prinsipnya ada dua macam drainase, yakni drainase untuk daerah perkotaan dan drainase untuk daerah pertanian. Pada perencanaan dan pengembangan sistem drainase kota perlu kombinasi antara pengembangan perkotaan, daerah rural, dan daerah aliran sungai atau DAS.

Drainase memiliki berbagai fungsi, antara lain membebaskan suatu wilayah (terutama yang padat pemukiman) dari genangan air atau banjir, memperkecil risiko kesehatan lingkungan, yakni bebas dari malaria (nyamuk) dan penyakit lainnya, sebagai pembuangan air rumah tangga . Ukuran dan kapasitas saluran sistem drainase semakin ke hilir semakin besar, karena semakin luas daerah alirannya. Adapun berbagai kendala di dalam pemeliharaan sistem drainase di wilayah kota dengan permukiman yang padat: kurangnya lahan untuk pengembangan sistem drainase karena sudah berfungsi untuk tata guna lahan tertentu, sulitnya memelihara saluran karena bagian atas sudah ditutup oleh bangunan, banyaknya sampah domestik yang menumpuk di saluran sehingga mengurangi kapasitas dan menyumbat saluran. Pemahaman masyarakat bahwa sungai (drainase) sebagai tempat buangan sudah menjadi budaya yang sulit dihilangkan. Terbatasnya dana untuk pemeliharaan saluran. Sistem drainase seringkali tidak berfungsi optimal karena pembangunan infrastruktur lainnya yang tidak terpadu dan tidak melihat keberadaan sistem drainase seperti jalan, kabel TELKOM, pipa PDAM. Secara estetika, drainase bukan merupakan infrastruktur yang bisa dilihat keindahannya karena fungsinya sebagai tempat pembuangan air dari semua sumber. Umumnya drainase di perkotaan kumuh dan berbau tidak sedap (Kodoatie dan Sjarief, 2005).

Beberapa gangguan terhadap sistim drainase perkotaan dapat berupa gangguan yang disebabkan faktor sosial budaya, gangguan teknis, gangguan lingkungan (Mulyanto, 2013). Gangguan yang disebabkan faktor sosial budaya terkait dengan rendahnya kesadaran masyarakat terhadap pentingnya fungsi sistim drainase bagi kesehatan lingkungan mereka. Gangguan teknis terkait dengan pembuatan drainase tertutup serta membangun bangunan diatasnya. Selain itu pemeliharaan drainase yang tidak rutin dilakukan sehingga menimbulkan sumbatan akibat dari proses sedimentasi atau penumpukan sampah di dalamnya. Gangguan lingkungan terkait dengan masuknya sampah dan limbah ke dalam saluran drainase yang mengakibatkan penurunan kualitas air yang mengalir atau air resapan di dalam tanah.

Kondisi kota Semarang saat ini sangat memprihatinkan bila dilihat dari kerusakan lingkungan. Penelitian yang pernah dilakukan oleh Suliyati (2011) menunjukkan bahwa banyak kawasan yang menjadi aset budaya dan obyek wisata semakin lama akan ñtenggelamò karena banjir dan rob. Beberapa contoh kawasan yang rusak adalah kampung Melayu, Bandarharjo dan kawasan Kota Lama (Little Nederland). Untuk itu perlu kemauan besar dari 
pemerintah kota dan seluruh masyarakat untuk menyelamatkan kota Semarang dari ancaman banjir yang akan menenggelamkan serta mengembalikan keindahan lingkungan Semarang.

\section{PENATAAN DRAINASE SEMARANG BUDAYA}

\section{SISTEM KOTA MELALUI}

Menurut Kodoatie dan Syarief (2006) penganganan banjir harus dilakukan secara terpadu, yaitu suatu proses yang mengutamakan koordinasi dan organisasi terkait dengan tindakantindakan pencegahan (preventive), pengurangan (mitigasi), persiapan, respon darurat dan pemulihan. Dalam pengelolaan banjir harus memperhatikan domain pengairan, kehutanan serta tata ruang provinsi dan kabupaten dalam pengelolaan tanah dan air serta peran serta masyarakat. Pengelolaan banjir tidak dapat dilaksanakan secara terpisah-pisah, tetapi harus dilaksanakan dalam sistim yang menyeluruh dan terpadu mulai dari hulu sampai hilir. Permasalahan banjir perkotaan/wilayah tidak sematamata persoalan teknis, tetapi juga terkait erat dengan masalah non teknis yaitu kondisi sosial, budaya dan ekonomi masyarakat. Oleh karena itu, penyelesaian permasalahan banjir perkotaan memerlukan partisipasi masyarakat, terutama dalam hal operasional dan pemeliharaannya (Dewi, Ni Putu Ety Lismaya, 2013: 2).

Penanganan banjir tidak hanya menjadi tanggungjawab pemerintah, tetapi juga menjadi tanggung jawab seluruh masyarakat, baik masyarakat yang ada di pedesaan, perkotaan dari semua lapisan dan golongan.
Pemerintah pusat dalam melaksanakan otonomi daerah telah memberikan kesempatan dan keleluasan kepada daerah untuk mengatur dan mengurus kepentingan masyarakat setempat menurut prakarsa sendiri berdasarkan aspirasi masyarakat (Situmorang 1999, dalam Sobriyah dan Wignyosukarto, 2001). Salah satu permasalahan masyarakat yang sering muncul adalah banjir yang terkait dengan penataan lingkungan yang buruk, memerlukan penanganan secara teknis maupun pendanaan yang besar, yang harus dilaksanakan oleh pemerintah dan peran serta masyarakat (Sobriyah dan Wignyosukarto, 2001).

Salah satu bentuk partisipasi masyarakat dalam penanganan penataan drainase adalah kegiatan gotong royong yang sudah mengakar dalam budaya masyarakat Indonesia. Gotong royong dalam bentuk tolong menolong merupakan solidaritas sosial dan tanggung jawab moral dalam suatu komunitas. Kegiatan kerjabakti sebagai gotong-royong dilakukan secara serentak untuk menyelesaikan suatu pekerjaan yang hasilnya dimanfaatkan bersama (Koentjaraningrat dalam Sajogyo dan Sajogyo, 1992: 38). Masyarakat perkotaan yang sangat materialistis menyebabkan nilai-nilai gotong royong mulai memudar. Demikian pula solidaritas sosial masyarakat perkotaan mulai bergeser maknanya.

Secara umum drainase di perkampungan Semarang terlihat belum tersentuh oleh partisipasi masyarakat atau kegiatan yang didasari kegotong-royongan. Kalaupun ada partisipasi masyarakat dalam pengelolaan dan penataan drainase, hal tersebut belum dilaksanakan secara maksimal dan berkelanjutan. 
HUMANIKA Vol. 19 No. 1 (2014) ISSN 1412-9418

Penataan Drainase Perkotaan Berbasis Budaya

Titiek Suliyati

Bagaimanapun keterlibat-an masyarakat dalam pengelolaan dan penataan drainase sangat penting untuk mempercepat terciptanya lingkungan yang tertata dan bebas banjir. Masyarakatlah yang terkena dampak paling parah dari kondisi banjir yang diakibatkan oleh sistem drainase yang buruk.

Salah cara untuk menata dan mengelola drainase di perkampungan kota adalah meninggkatkan budaya gotong royong dalam bentuk kerja bakti secara kontinyu di lingkungan masyarakat. Selain itu para generasi muda juga dididik untuk memiliki budaya bersih, tidak hanya r̃bersih diriô tetapi juga ñbersih lingkunganò. Secara umum budaya ñbersih lingkunganò belum dihayati masyarakat Indonesia, baik di pedesaan maupun perkotaan. Hal ini terbukti dari sikap masyarakat yang sangat acuh terhadap lingkungan, seperti membuang sampah di sungai atau selokan, membiarkan lingkungan sekitar tidak terawat dan kotor, mendirikan bangunan di atas selokan atau saluran drainase dan lain sebagainya.

Masyarakat kota yang sangat heterogen dan memiliki sifat-sifat individualistis yang tinggi demikian acuh dengan penataan lingkungan di sekitarnya, terutama penataan drainase. Penataan dan pengelolaan drainase di perkampungan-perkampungan kota dianggap sebagai hal yang sepele dan tidak penting, padahal akibat dari kondisi drainase yang buruk dapat menimbulkan bencana yaitu banjir. Jika bencana banjir ini melanda perkam-pungan kota setiap saat, maka masyarakat yang dirugikan.

Dasar-dasar tradisi yang berakar dari kearifan lokal, yang memberikan perhatian pada pengelolaan lingkungan sebenarnya telah tumbuh di lingkungan masyarakat Indonesia. Tradisi dan budaya yang memberikan perhatian pada pemeliharaan lingkungan sekitar berkaitan dengan pemeliharaan hutan, pemeliharaan sumberdaya air, pengelolaan dan pengolahan tanah pertanian dan sebagainya telah dilakukan oleh masyarakat pedesaan.

Tradisi dan budaya ñarif lingkunganò perlu dihidupkan dan dikembangkan di lingkungan masyarakat pedesaan maupun masyarakat perkotaan (Suhardi, 2000: 331). Bagaimanapun banjir yang terjadi di kota Semarang, juga karena terjadinya penggundulan hutan di wilayahwilayah pedesaan yang terletak pada lokasi yang lebih tinggi dari kota Semarang. Oleh karena itu, budaya ñarif lingkunganò dan budaya gotong royong harus terus ditumbuhkan di lingkungan masyarakat pedesaan dengan cara selalu mensosialisasikan bahwa penggundulan hutan akan menyebabkan banjir di wilayah yang terletak dibagian bawah. Masyarakat desa juga dihimbau untuk menjaga hutan dan menanam kembali pohonpohon pengganti. Demikian juga di kalangan masyarakat kota Semarang diharapkan memiliki kesadaran ñarif lingkunganòdan ñobersih lingkunganñ

Cara untuk menumbuhkan kesadaran ñarif lingkunganò dan ñbersih lingkunganò dengan menggalang solida-ritas sosial melalui kegiatan gotong royong secara kontinyu dan berke-lanjutan untuk membersihkan dan memelihara saluran drainase di sekitar lingkungannya. Untuk membersihkan dan memelihara saluran drainase primer (utama) seperti sungai-sungai besar, pemerintah kota dapat melakukan kegiatan-kegiatan 
gotong royong atau kerja bakti masal yang diikuti oleh masyarakat umum secara bergiliran waktunya. Kegiatan ini dapat dikemas dalam bentuk acara tradisi yang sesuai dengan budaya masyarakat setempat.

Untuk menumbuhkan kesadaran dan partisipasi masyarakat dalam pengelolaan drainase membutuhkan waktu yang lama dan sampai saat ini usaha tersebut belum menampakkan hasil yang memuaskan. Walaupun demikian, perlu upaya terus menerus untuk mendidik seluruh lapisan masyarakat mulai dari usia dini sampai usia lanjut melaui pendidikan formal maupun non formal, agar mereka memiliki kesadaran ñarif lingkunganò dan r̃bersih lingkunganò

Partisipasi masyarakat perlu terus digalang melalui peranserta para tokoh masyarakat, tokoh adat, tokoh agama dan para pemegang kebijakan di kota Semarang. Para tokoh ini dapat berperan sebagai motivator, creator dan evaluator. Melalui para tokoh ini dapat diharapkan perencanaan, pelaksanaan dan pengawasan pengelolaan dan penataan drainase perkotaan melalui aktivitas budaya dapat berhasil.

\section{V.SIMPULAN}

Masalah banjir di beberapa kota besar termasuk kota Semarang bukan hanya menjadi masalah dalam skala kota saja, tetapi telah menjadi masalah nasional. Penanganan banjir dari aspek teknis telah dilaksanakan, tetapi belum membuahkan hasil. Penangan banjir harus dilaksanakan secara menyeluruh dan terpadu, baik dari aspek teknis dan aspek sosial kemayarakatan. Kerjasama antara pemerintah kota dengan masyarakat secara terpadu harus mulai dirintis, baik aspek pendanaan maupun aspek sosial.

Masyarakat sebagai penghuni kota sangat besar perannya terhadap perusakan lingkungan maupun pemeliharaan lingkungan. Dalam penanganan banjir partisipasi masyarakat sangat diharapkan, bukan saja pada saat terjadinya bencana banjir, tetapi yang lebih penting adalah melakukan pen-cegahan banjir melalui pengelolaan saluran air (drainase) sampai pena-nganan dampak banjir.

Partisipasi masyarakat dalam pengelolaan drainase dapat dirancang sebagai keja bakti gotong royong yang sifatnya kontinyu. Selama ini di lingkungan masyarakat bentuk kerja bakti dan gotong royong masih sering dilakukan secara parsial. Kerja bakti dan gotong royong dalam skala besar dan luas dapat dilakukan untuk menangani drainase atau saluransaluran air yang besar seperti sungai. Pemerintah kota melalui bantuan perangkatnya dari tingkat RT, RW, Kepala Desa/lurah, camat maupun walikota/bupati dapat merancang kegiatan kemasyarakatan bersih-bersih sungai/saluran air secara bergiliran antar RT/RW, desa atau kecamatan. Kegiatan dapat dikemas dan disesuaikan dengan tradisi-tradisi yang masih hidup di lingkungan masyarakat, misalnya tradisi ñbersih desaò, röersih kampungò atau ñbersih sumberò dan lain sebagainya.

Selain itu, acara kerja bakti secara gotong royong juga dapat dikaitkan dengan peringatan hari-hari besar nasional seperti peringatan hari kemerdekaan Republik Indonesia atau peringatan hari besar agama seperti menyambut bulan suci Ramadhan atau tanggal 1 Syura. Dengan demikian, 
HUMANIKA Vol. 19 No. 1 (2014) ISSN 1412-9418

Penataan Drainase Perkotaan Berbasis Budaya

Titiek Suliyati

kegiatan kerja bakti secara gotong royong akan sangat menggembirakan bagi masyarakat karena ada kemeriahaan dan kegembiraan. Melalui kerja bakti dan gotong royong, diharapkan terjalin solidarita sosial yang tinggi dari masyarakat kota dalam mengelola lingkungan pada umumnya dan drainase pada khususnya.

\section{DAFTAR PUSTAKA}

Dewi, Ni Putu Ety Lismaya. (2013). ñPartisipasi Masyarakat dalam Operasional dan Pengelolaan Sistem Jaringan Drainase di Kota Denpasarò dalam Jurnal Media Bina Ilmiah Volume 7 No.3. 2013. ISSN No. 1978-3787

Departemen Pemukiman dan Prasarana Wilayah. (2003). Panduan dan Petunjuk Praktis Pengelolaan Drainase Perkotaan. Jakarta.

Hadi, Sudharto P. (2005). Dimensi Lingkungan Perencanaan
Pembangunan. Gadjah Mada University Press.

Yusuf, Y. (2005). Anatomi Banjir Kota Pantai Perspektif Geografi. Surakarta: Penerbit Pustaka Cakra.

Kodoatie, R.J. \& Sjarief, R. (2005). Pengelolaan Sumber Daya Air Terpadu. Yogyakarta: Penerbit Andi.

(2006). Tata Ruang Air. Yogyakarta: Penerbit Andi.
Koentjaraningrat. (1983). ñ Ciri-Ciri Kehidupan Masyarakat Pedesaan di Indonesiaò dalam Sajogyo dan Sajogyo, Pudjiwati. Sosiologi Pedesaan. Jilid 1. Yogyakarta: Gadjah Mada University Press.

Mulyanto, H.R. (2013). Penataan Drainase Perkotaan. Yogyakarta: Graha Ilmu.

Mutaqqin, A.Y. (2006). Kinerja Sistem Drainase Yang Berkelanjutan Berbasis Partisipasi Masyarakat Studi Kasus di Perumahan Josroyo Indah Jaten Kabupaten Karanganyar). Tesis. Semarang: Universitas Diponegoro.

Pramono, S.S. (2002). Analisis Penyelesaian Masalah Banjir di Kota Semarang dengan Pendekatan Sistem Peringkat Komunitas (SPK). Jurnal Desain dan Konstruksi Vol. 1. No. 2. Desember 2002: 108-115.

Rencana Pembangunan Jangka Menengah Daerah (RPJMD) Kota Semarang Tahun 20102015 .

Sajogyo \& Sajogyo, Pudjiwati. (1992). Sosiologi Pedesaan. Jilid 1 dan 2. Yogyakarta: Gadjah Mada University Press.

Suliyati, Titiek. (2012). Model Pemetaan Kawasan Pemukiman Bersejarah yang Berbasis Budaya dan Bersinergi dengan Aktivitas Masyarakat di Semarang. UNDIP. Hasil penelitian tidak diterbitkan. 
Sobriyah \& Wignyasukarto, Budi. (2001). ÒPeran Serta Masyarakat dalam Pengendalian Banjir untuk Mendukung Pelaksanaan Otono-mi Daerahò Makalah pada Kongres VII dan PIT VIII Himpunan Ahli Teknik Hidraulik Indonesia (HATHI), Malang 2001.

Sobriyah. (2005). Sistem Pendukung Keputusan Pada Penentuan Prioritas Rehabilitasi Jaringan

Irigasi di DIY. Jurnal Gema Teknik Fakultas Teknik Universitas Sebelas Maret.
Suhardi. (2000). Budaya Arif Lingkungan dan Solidaritas Sosial: Konteks Konservasi Sumberdaya Non-hayati, Jurnal Humaniora Volume XII No. 3.

Suripin. (2004). Sistem Drainase Perkotaan yang Berkelanjutan. Yogyakarta: Andi Offset.

Wiganingrum, Anditya., S, Leo Agung \& Wahyuni, Sri. (2013). Nilai Kearifan Upacara Tradisional Susuk Wangan Sebagai Bentuk Solidaritas Sosial dan Pelestarian Lingkungan di Desa Setren Kecamatan Slogohimo Kabupaten Wonogiri. Program Studi Pendidikan Sejarah FKIP UNS. Jurnal Candi - Jurnal Pendidikan dan Penelitian Sejarah, 5 (1). 